\title{
Traditional Way of Forest Management on Yakushima Island
}

\author{
Izumi HARAGUCHI Faculty of Law, Economics and the Humanity, Kagoshima University, 890 Kagoshima, Japan.
}

\begin{abstract}
Key Words: Yaku-cedar / Hiragi / Houkouji-temple / Satsuma-clan / Jochiku Tomari / the Ryukyu Kingdom / monopoly system / Iriai-yama (commonage)
\end{abstract}

Although throughout the years the people of Yakushima have maintained a deep relationship with the Yaku cedar forest, these forests have been regenerated. This close co-existence between humans and nature is one point that is held in high regard and considered to be a good example of how such coexistence can be maintained.

The question one must ask then is how the ecosystem of these forests has been maintained despite this close interaction over the years.

First of all, let me explain what Yaku-cedar trees are like. Trees more than 1,000 years old are called Yaku-sugi cedar, younger ones being known as Kosugi (small-sized cedar). A characteristic of Yaku cedar trees is that as they get older and the rings pack tight together they produce a lot of resin, and this protects them from decay. It was for this reason that Yaku cedar trees were used to produce"Hiragi" or shingle (flat roof tiles) in the Edo period. Also, Yaku cedar trees are excellent for lumber goods because as I mentioned above they contain a lot of resin and they have a fine grain and look very beautiful. For example, it reminds me of the guest room at Honrenji temple in Ushimadocho, Okayama prefecture. The modern ceiling panels were constructed in 1724 , but still maintain its beautiful shape. Honrenji temple was used for the lodging and receiving of a delegation from Korea.

\section{RELATIONSHIP BETWEEN YAKU CEDAR TREES AND PEOPLE}

Looking back on the relationship between Yaku cedar trees and people of ancient times to present day, we can divide the period into 4 stages.

1) "The Tree of God" till 1641 Yaku Island was an object for mountainous religions, and as a result, cutting down of Yaku cedar trees was prohibited. People on the island feared God's revenge for cutting down trees of God. Trees for the use of people such as "Kosugi" or small sized cedars were cut only at the area of the foot of mountains and even with this fact they could satisfy the people's demand.

2) Yaku cedar trees as "Kate" or a yearly tribute, and "Hiragi or shingle in the Edo period from 
1642 to 1867 (225 years) about 50 to $70 \%$ of Yaku cedar trees were cut down, but since people used only manual power to cut down the trees, it provided enough time for plants (cedar ) for the alternation of generation.

3) Industrial resources In modern contemporary times, for about 100 years (1868-1969) felling and transporting methods were mechanized, and trees of particular districts were all cut down by chain-saws. For example, refer to the station in Kosugidani in Yaku island in about 1965.

4) Yaku cedar trees' ecological value Yaku Island was designated as a world heritage site in 1993. The conventional method of felling (240 year cycle is necessary for alternation of generation), "gunjoutakubatsu-system" has been practiced. Today, the felling of Yaku cedar trees more than a 1,000 years old is prohibited, and Domaiboku or old stumps are processed for Yaku-cedar goods such as traditional crafts.

\section{HISTORY OF YAKU CEDAR DEVELOPMENT: MONOPOLY SYSTEM ON YAKU CEDAR TREES}

\section{Introduction of Yaku cedar development and its law regulation}

The first Japanese to make use of Yaku cedar trees for the first time was the high-ranking priest, Nisshu Shounin. After he landed on Ryukyu Island and served the Shimazu clan in Satsuma, now called Kagoshima, he came to be engaged in the reconstruction work of Kagoshima Shrine which was burned during the upheavals of the warring state in those days. For the construction of the shrine, he utilized Yaku cedar trees (1560). The reason why Nisshu could cut Yaku cedar trees which had been regarded as "trees of God" by ordinary people was partly because he was a high-ranking priest and partly because Yaku cedar trees were to be utilized for the construction of the temple which had a long and distinguished history. The following case in which Yaku cedar trees were used was in the time of the construction of the huge image of Buddha at Houkouji-temple in Kyoto.

After Hideyoshi Toyotomi united Japan, he ordered all the Daimyos or lords nationwide to supply wood, he pressed the Shimazu clan to present big Yaku cedar trees (1587 -1589). At this time it was recorded that the Shimazu clan dispatched some officials to research big Yaku cedar trees on the island, but from that report there was no such record that wood was transported to Kyoto.

However, from the fact Hideyoshi Toyotomi was then at the height of his power we can imagine that there was no possibility that the Shimazu clan would refuse to carry out the order.

Houkouji-temple after being completed ended up completely destroyed due to the great earthquake in 1596. Reconstruction work on the temple started in 1610 and was completed two years later in 1612. According to the records, we can recognize the fact that Yaku cedar trees were used in the reconstruction. Also according to the records, Shoudo-shima in the Inland sea of Seto, seamen in Shoudo-shima boarded 11 ships to transfer the lumber. Wilson stump was the stump made around this time. The fact that Yaku cedar trees were utilized for the construction of Houkouji-temple could be compared to the fact that Kagoshima shrine was constructed, both of which were of course for the purpose of constructing religious buildings. It can be said that the Toyotomi family and the Tokugawa family made use of Yaku-cedar trees for constructing state buildings. Yaku cedar trees were not used in the construction of just ordinary buildings.

In fact, the Shimazu family issued the order; "Yakushima-okime" in 1595, strictly regulating the use of Yaku cedar trees. The order, "Okime" was comprised of five articles:

1. High quality trees or aged big trees should be presented to the central government or to the Shimazu clan in case of necessity. 


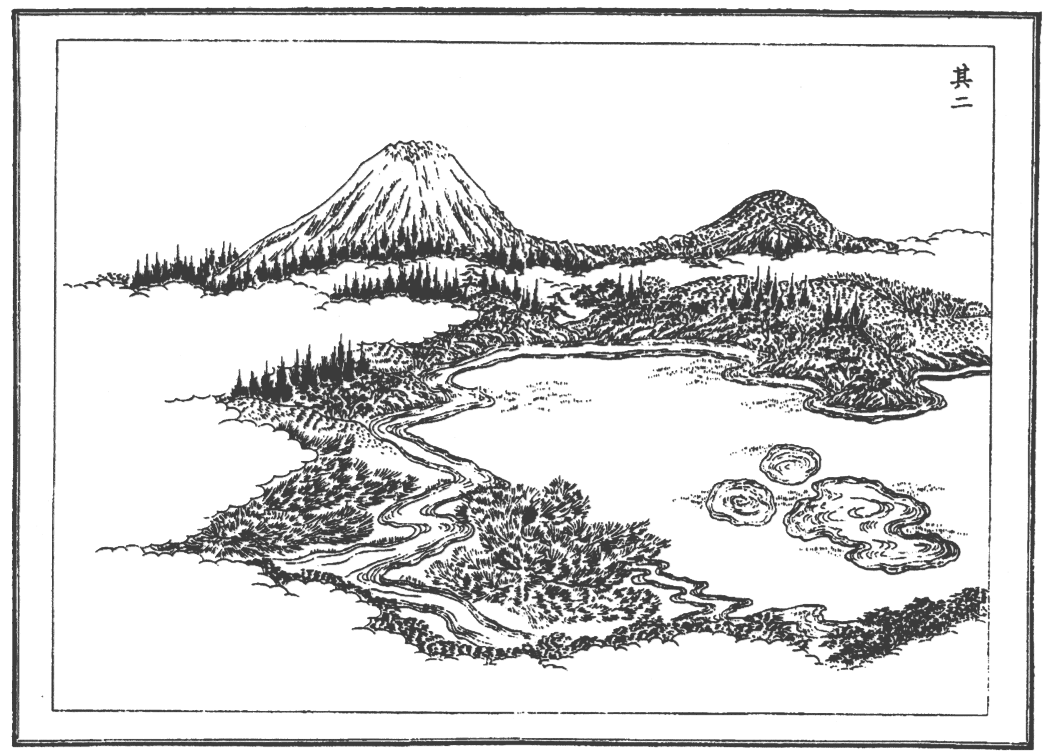

Fig. 1. Hananoegou, Yakushima Island. (Sangoku Meishou Zue)

2. Transporting lumber to other countries by ordinary people was prohibited. Foreign ships buying lumber were not allowed to call on Yaku island.

3. Detailed directions (agreements that had been made beforehand between them) were given to the people of Yakushima by messengers dispatched by the Shimazu clan.

4. At the time of the investigation of lumber for constructing a great Buddha at Houkouji-temple, some trees were registered and were written in a record stating that those trees should be observed continuously.

5. Trade business of lumber should be done with the deep consideration.

Until this time, the cutting down of trees by Islanders was restricted to small sized cedar trees or other types of trees; not Yaku cedar trees, only at the foot of mountains.

\section{Establishment of the monopoly system on Yaku-cedar trees: direct management by the clan}

When did Yaku-cedar trees come to be commonly used? The time when Yaku-cedar trees came to be commonly used was in 1642. It was by the proposal of Jochiku Tomari (1570 - 1655) for development of Yaku cedar trees to the Satsuma clan. Jochiku Tomari was a high-ranking priest from Anbou on Yaku Island, he was a Confucianist, at first he served the king of Ryukyu and later became a tutor for the Lord of Shimazu. At the time Ryukyu was under the forced control of the Shimazu family (1609 ). Jochiku might have thought that Yaku-cedar trees should be utilized for the reconstruction of the capital of the Ryukyu Kingdom which was burned down in the aggression of the Shimazu family.

The main purpose of Yaku-cedar tree development was attributed to the financial problems of the Satsuma clan. During the Edo period, the Satsuma clan was the second biggest clan in Japan, but agricultural productivity in Satsuma was low and the Shimazu clan was suffering from extreme financial difficulties. Therefore, the clan government directed its attention to the development of Yaku cedar trees which had a high commodity value, yet Islanders were still afraid of these so called "trees of God", and were reluctant to cut them down recklessly. I think the process was made in a style that Jochiku, in whom islanders had much trust, was told to make the proposal to the islanders, Jochiku had from the beginning been called the "Yaku Saint". 
Nevertheless, Yaku cedar trees came to be extensively logged from 1642, becoming not only a large, but main financial source for the Shimazu clan. According to the book "Sangoku-meishou-zue" in 1842, "Jochiku expressed his grief to find out that the high quality trees were not in world use, and went deep into the mountain and prayed to the God of the mountain for 17 days to ask for permission to utilize Yaku cedar trees for world use. Since then islanders started to cut down cedar trees." If this is so, Jochiku can be the founder of Yaku cedar development. At the moment, we should pay attention to his remark warning against destructive development. In the book, "Sangoku-meishou-zue" an interesting quotation can be found: "Try cutting down a tree, if you can't cut it down it is one of the trees God wouldn't give permission to the people to cut". This quotation is of course an admonition of reckless deforestation.

Introduction of a system of paying tax by Yaku cedar (in the form of Hiragi or flat roof tiles)

The Satsuma clan, having been suffering from financial difficulties, came to ask its financial resource to Yaku cedar as time went by. That is to say the clan ordered islanders to pay a yearly tribute, not in the form of rice but in the form of "Hiragi".

In 1726, a land survey of the whole of Yaku island was conducted. At that time land productivity in Japan was expressed in terms of rice yield. Rice yield as expressed by '"koku" (1 koku = 180.39 l) in the Tokugawa era, and the amount of koku on Yaku island was calculate of 1,385 koku in 1726.

In 1728, "Yakushima-tegatasho-kimochou" was published. In the book the rate of exchange for Hiragi or wood and rice was shown. 1 koku of rice $=14,000$ pieces of Hiragi (Hiragi $=10 \mathrm{~cm}$ in width and $40 \mathrm{~cm}$ in length).

Here is a tentative calculation for how much Yaku Island had to pay in yearly tributes.

$1,380 \mathrm{koku} \times$ rate of an yearly income $(80 \%)=5,000 \mathrm{~m}^{3}$

From the calculation above, about $5,000 \mathrm{~m}^{3}$ Yaku cedar trees a year was logged. Therefore, Islanders had to pay taxes in wood and exchanged timber for daily necessities. In fact, the volume of Yaku cedar trees cut down was considered to be much more than $5,000 \mathrm{~m}^{3}$.

\section{Comparison of Annual felling volume}

The number mentioned above was about one thirtieth the yearly felling volume of $150,000 \mathrm{~m}^{3}$ in 1967. This comparison shows the difference of technology between cutting tools of the Edo period and the present. At the same time, the clan was also afraid of lacking natural resources and it made the clan moderate land development. The clan forced all the islanders to plant seedlings as their duty.

\section{Obligation of afforestation}

Not only lumberjacks (in order to show their appreciation for felling trees) but also all islanders were required to plant seedlings. Nowadays only the people engaged in the forestry industry and the central government of Japan undertake such planting. Therefore, the purpose of a monopoly system was considered to maintain financial resources for the clan and to deal with the protection of lacking natural resource.

\section{Difference of technique for cutting trees}

During the Edo period, techniques of felling were in a sense not mature. Felling had all been done by manual power; later, trees were cut down into pieces of Hiragi on the mountain. Transport of Hiragi was done by people carrying them on their backs walking down the rough mountain road. Transporting Hiragi from Yaku-island to the mainland Japan was by ship. Therefore, thinning out 
trees in the forest by manual power was limited to the extent that hard trees were left behind uncut and in other cases, comparatively high portions of trees were cut because huge ladders were formed for cutting and stumps were left behind. From there new trees were putting forth their buds. (It had an effect of pruning). At present, chain- saws, trucks and steamers have replaced manual power, resulting in the trees being uprooted.

\section{MEASURES FOR MAINTAINING THE BALANCE OF LOCAL INDUSTRY}

\section{Promotion of other industries besides forestry}

Around 1783, 50 years after the introduction of the Yaku cedar monopoly system, flying fish having been considered to be bad in the past, was spotlighted. Flying fish fishing in turn became prosperous. It was because forests started to become endangered as a result of reckless deforestation. In order to protect the mountains, the clan encouraged islanders to engage in side businesses outside of forestry. In other word, mountain destruction was becoming so terrible that the clan could not help promoting side business. Because of this, on Yaku island, other industries in addition to forestry developed. For example, fishery; fish such as flying fish, bonito, mackerel, and Yaku shell fish have been caught (Aristocracy acquired a taste for Yaku shell fish in the Heian Era). Another example is medicinal herbs "Gajutsu" or cochin turmeric business begun. In the end, islanders were involved in forestry, agriculture, fishery, and even involved in the shipping business as well.

\section{Relationship of the land system: commonage of "Iriai-Yama"}

Finally, I would like to mention some traditional ways of forest management on Yaku Island. Paying specific attention to the land system, generally laws are divided into roughly two parts, German law and Roman law. The characteristic of German law is to require unanimous agreement of the members on the issue of the development of commonage; while in Roman law, the decision is made by majority vote. In this respect, Roman law is said to be Merchant law. Accordingly, it is a matter of fact the German law is appropriate for the preservation of forests while Roman law for the promotion of land development. In the Edo period, the land system adopted for forests on Yaku island existed in the form of commonage called Iriai-Yama. When adopting Iriai-Yama, Islanders were free to pick up fire wood, make charcoal, as well as grow mushroom and fertilizer for growing rice in the paddy fields. This type of commonage was developed in Tanegashima Island. On Tanegashima, it is called Maki. There were many Maki on Tanegashima because it was needed to meet the need for stockbreeding, salt manufacturing. At present, by the introduction of new land reform in Japan, the private right of possessing land was decided. Even in that case, Maki was regarded to be land for communal use of the local people. In order to develop this type of jointly owned land, unanimous agreement was required, and as a result the effect for preservation of forest can be seen. In other words, the land system on Yaku island was influenced by German $1 \mathrm{aw}$.

Let me quote some remarks from "Sangoku-meishou-zue 1642". "Leave an axe in the Yaku cedar over night which people are going to cut. In case it falls down to the ground the next day, it meant the tree should not allowed to be cut down because it was a tree of God". I think that there are two important meanings in this remark of Jochiku. First, one needs all night to think profoundly over whether the tree should be cut down or not if somebody wants to cut down the Yaku cedar. Second, if someone is against cutting down the tree he can prevent people from cutting the tree by falling the axe. In short, German law says there should be no one among related members who is against the proposal and the theory can be found in the practice on Yaku-island. 


\section{SUMMARY: IN CONCLUSION}

During the Edo period, mountains on Yaku-island were managed conventionally by technological regulation in terms of the manual felling of trees and by a land system called "commonage". From the initial development stage of Yaku cedar trees, Jochiku, who started the utilization Yaku cedar trees warned against environmentally irresponsible development while the clan put strict regulations into effect to avoid exhaustion of resources and made efforts to raise forests. In the Edo period, religious events close to the mountains such as "Takemairi" were continuously held and the people focused their beliefs on the mountains while they utilized the mountains and forests. In 1881 land reform was put into effect. Most of the forests were designated national forests. By this act of reform, islanders rights for earning from the mountains was taken away.

1890 - Submitting a petition for bringing forests back under private ownership

1904 - Action against the state 1921 - Yakushima constitution, an order of management of Yakushima national forest was formed.

Lastly, if I would like to make a suggestion to Yaku island, I suggest that compound industries should be taken into consideration. During premodern times, the industries of Yaku island comprised of forestry, agriculture, fishery and shipping . At present Yakushima has the potential to realize ecotourism and education "Industry".

To hand Yakushima to the next generation while protecting the valuable eco-system of Yaku island is a difficult task. Not only should strict superficial regulations be strengthened but also offering a constant secure life to the islanders is needed. Also maintaining the eco-system to cooperate with the islanders is required. Finally, people outside the island must feel a strong desire to assist in inheriting world heritage, Yakushima.

\section{REFERENCES}

Sangoku Meishou Zue (三国名勝図会), vol. 5. Reprinted by Seichousha, Kumamoto, 1982.

Sappan Kyuki Zatsuroku (薩藩旧記雑録), vol. 2. Kagoshima Pref. 1982.

Nihon Rinseishi Shiryou, Kagoshimahan (日本林制史資料, 鹿児島藩), 1933. Ministry of

Agriculture \& Forestry, Japan.

\section{原口＼cjkstart泉＼cjkstart屋久島における伝統的な森林保護システム}

屋久杉と人間との関係は，歴史的に 4 つの段階に区分される。それは :

(1)「神木としての屋久杉」( 1641 年まで), 屋久島は山岳信仰の対象であり, 人間が利用する 木は里山で足りていた。

(2)「糧としての屋久杉」(1642 1967 年), 屋久杉の本格的な伐採が始まる。斧を使って伐らざ るを得なかったため, 屋久杉は世代交替することができた。

(3)「資源としての屋久杉」(1868～1969), 屋久杉が最大限利用された。伐採・運搬の機械化が 進み, 昭和 40 年代の小杉谷のように一定地域が皆伐された。

（4）「自然環境としての屋久杉」 $(1970 ）$, 屋久島は貴重な自然環境として高く評価されるよう になり。1993年世界自然遺産に登録された。

この第 2 期の近世から第 3 期の近現代まで屋久杉は一貫して伐採されてきたが，すぐれた森林生態 系が維持されてきた。この点で人間と自然との共生の好事例として高く評価されている。

宗教的 - 国家的建築への屋久杉利用近世以前, 屋久杉は大隅国正八幡宮の再建 (1560) や京都方 広寺大仏殿の再建（1610～1612） などに限られていた。1595 年，島津氏は屋久島の大木の調査を行 
うとともに,「屋久島置目」を発布た。

屋久杉の一般的利用と専売制の確立 屋久杉の開発を藩に提言したのは, 安房出身の儒学者・泊如 竹（1570～1655) であるといわれている。屋久杉は 1642 年から広く伐採されることになつた。そし て財政難に苦しむ藩は, 時代とともにいっそう屋久杉に財源を求めることになり, 島民の年貢米を平 木で上納することを命じた。1726年屋久島全島の検地が実施され, 生産高 1386 石が打ち出された。 ついで 1728 年「屋久島手形所規模帳」で米と平木の交換率（米 1 石 = 平木 14000 枚）が定められた。 年貢としての平木生産の伐採量は年当たり約 $5000 \mathrm{~m}^{3}$ と計算される。1967 年の年間伐採量 15 万 5000 $\mathrm{m}^{3}$ の 1/30 の量である。伐り出しは手䆑のみで, やぐらを組んで相当上の方で伐っていた。山からの 運び出しは, 人夫が背負って港まで運び, 運送は帆船であった。また, 藩の専売政策は, 資源が枯渴 しないよう，伐採者に「御礼杉」の植栽を義務づけた。さらに島民は林業一本ではなく，漁業（カツ オ, サバ, 飛魚漁), 農業 (薬草のガジュツ栽培等), そして一部には海運業もかねて生活している。

土地制度の在り方と森林保全は密接な関係がある。近世屋久島の山林は, 藩直営林や村民請負林で 構成されているが, 村持山は入会山であり, 村民が自由に利用できた。この村持山のような共同利用 地を新たに開発しようとすれば, 村民全員の一致が必要とされていたので, 慣行的な利用形態が存続 され，森林保全につながった。

近世の地租改正と国有林化 明治維新後, 屋久島に地租改正が実施され (1881年終了), 村持山の ように個人の所有が確定できない山林も含めて, ほとんどの山林が国有林となり, 山稼ぎ島民の入会 利用の自由が奪われてしまった。1921 年提示された「屋久島国有林経営の大綱」(「屋久島憲法」) は 島民の期待を裹切るものであった。国は 2 年後に約 7000 ha の山林を入会用地として設定したが, 国 有林が民有林になることはなかった。

近世における屋久島の山林は，島民の年貢としての屋久杉伐採にもかかわらず，伝統的に保護され， また岳参りという山への信仰も存続し, 保護育成されてきた。ところが国有林経営の下で, チェーン ソーにより皆伐され，トロッコで容易に運搬され，森林破壊が進められた。

世界遺産に指定された屋久島では農林漁業だけでなく, エコツーリズムや自然環境学習という新し い産業の活性化が実現可能である。屋久島の貴重な生態系を守り, 次世代に伝えるためには, 単に規 制を強化するだけでなく, 産業の複合化によって島民の生活安定をはかり, 島民が中心になって生態 系を守り，島外の人たちがそれを支援していく体制が必要である。 